直腸癌に対する double stapling technique を用いた 低位前方切除術の工夫

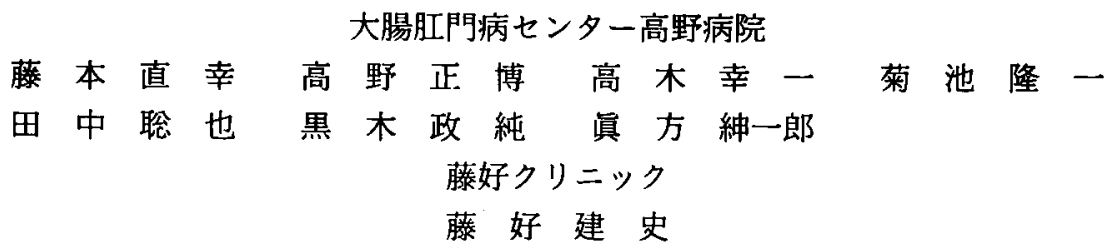

直腸癌に対して Double stapling technique (DST) を用いた低位前方切除術を行うに あたって, 以下の様な工夫を加えた. (1)口側腸管へAnvil を挿入する際, 食道癌の吻合 に用いる Flat Anvil を側壁よりボタンをかける様に挿入する. (2) PCEEA 本体を肛門よ り挿入する際, 肛門疾患の合併のため, 挿入困難な場合, 電気メスにて後方の内括約筋 を一部切開する. (3)術中ファイバーにて必ず吻合部を確認し, leak test を施行する. (4) 術後の吻合部狭窄に備えて，吻合部位をできるたけ第II指の届く範曲に置く.

過去 5 年間に施行した低位前方切除術138例中術後合併症は, 縫合不全 $9.4 \%$, 吻合部 狭窄5.1\%で, 一応満足すへき結果であった. DSTによる低位前方切除術は, より低位で の吻合が短期間で可能であり，術中の污染がなく，さまざまな夫を加えることによっ て，良好な成績が納められる方法と思われた。

索引用語：直腸癌, Double stapling technique (DST), 低位前方切除術 (LAR), 器械吻合 の土夫

\section{緒 言}

近年直腸癌の手術術式に関して, 括約筋温存術が主 流になりつつある。これは, 癌の根治性と患者の Quality of life の両面を追求したもので, 器械吻合の進歩, 殊に Double stapling technique (以下 DST) の導入 により可能になってきた. 直腸癌の低位前方切除術に 対して多くの施設で器械吻合が行われているが，この 方法を成功させる為には, 器械の操作法に習熟すると ともに，さまざまな工夫を加える必要がある，又，術 後合併症である縫合不全, 吻合部狭察などを極力併発 しない様に，充分注意することが重要である。

今回われわれは, DST を用いて低位前方切除術を行 う際の若干の工夫と, 術後の吻合部㹨䆓に対する対策 について考察を加えたので報告する.

\section{研究対象及び方法}

\section{(i) 対象}

1988年より1992年末でで138例, 男性85例，女性53例

1994年 4 月 15 日受付 1994年11月 9 日採用
の低位前方切除術にDSTを用いた。

\section{(ii）使用した吻合器}

米国センチュリーメディカル社製のEEAシリー ズ, Roticulator 55及び PCEEA (口径 $28 \mathrm{~mm}$ 大, $31 \mathrm{~mm}$ 大）を用いた（図 1).

\section{(iii）手術手技及びエ夫点}

(1) 体位は截石位とし,中下腹部正中切開にて開腹を 行い, 恥骨上縁の筋膜まで充分切開を加える. 腹膜切 離下縁の頂点及び両側縁を腹壁に縫着する. 尚, 女性. の場合子宮底部を挙上し, Cut-gut 糸にて腹壁に縫合 固定する. 次にトライツ勒帯下縁より回腸末端部の小 腸全てを小腸バッグに納め，右腹腔外に持ち上げコッ ヘル鉗子にて固定する.

(2) 腹腔内の操作手技は，通常の $\mathrm{R}_{3}$ 郭清を基本とし ているので, 詳細は割愛する. 必要に応じて自律神経 を温存している. 尚, 側方郭清の必要な症例に関して は, 腸管切離が終了した後施行している.

(3) 上方の郭清が終了し, 直腸後壁及び仙骨前面の剥 踓をある程度行った後, 腸管切離に移る.まず上方の 

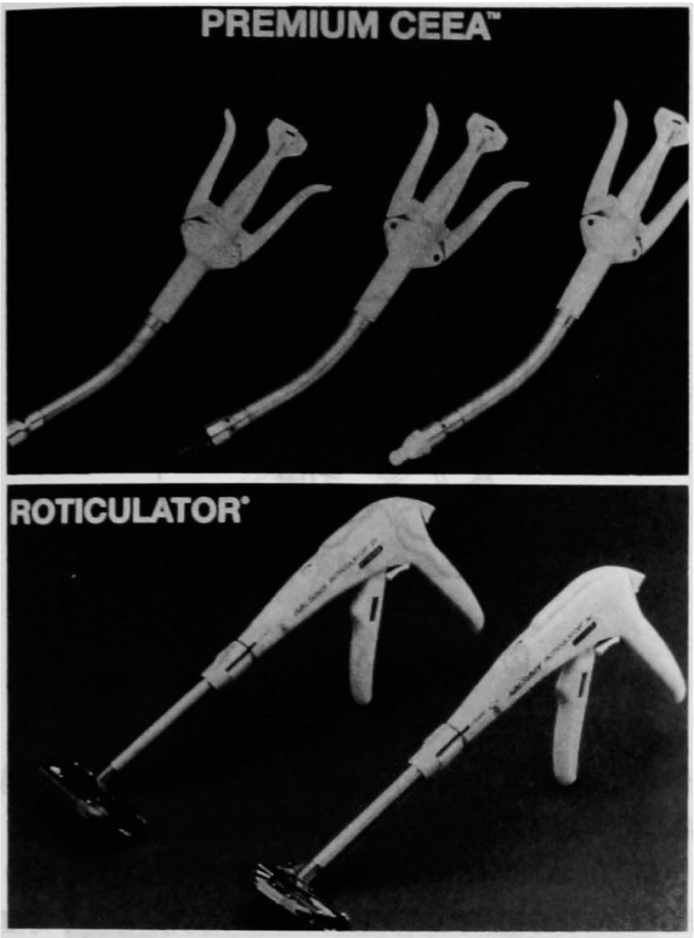

図 1

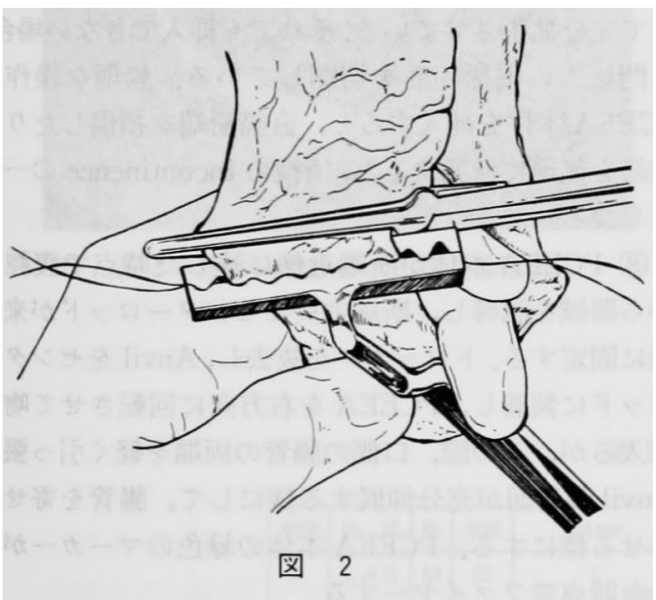

$\mathrm{S}$ 字状結腸の切離は夕バコ縫合器を用い, 肛側は中山 の断端鉗子をかけ，その間にて切離する(図 2 )。切離 後口側はタオルにて包み，左腹腔外に置く，purstring (ディスポーザブル)を用いた方法も行ってみたが，器 具が大きく手術操作上邪魔になるので，タハコ释合器 の方を使用している(図 3 )，Anvil の装着は，吻合操 作に入る直前に行う様にしている。

(4) 肛側の腸管切離は回転式ディスポ縫合器の

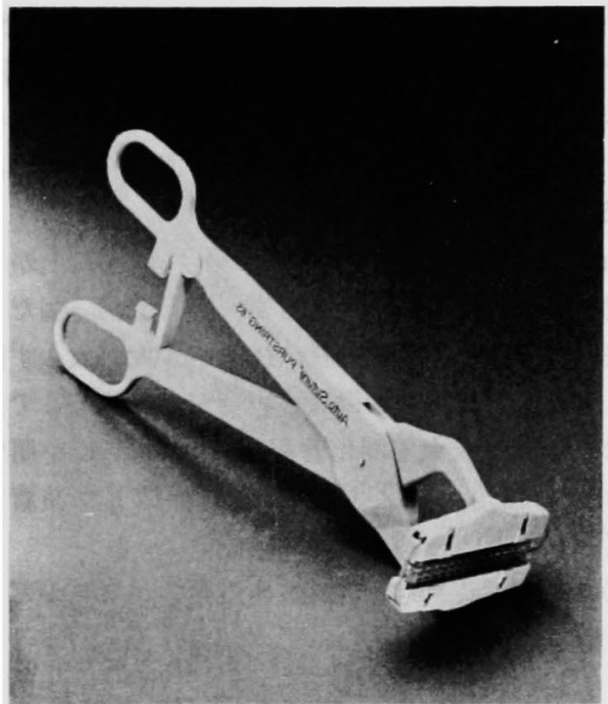

図 3

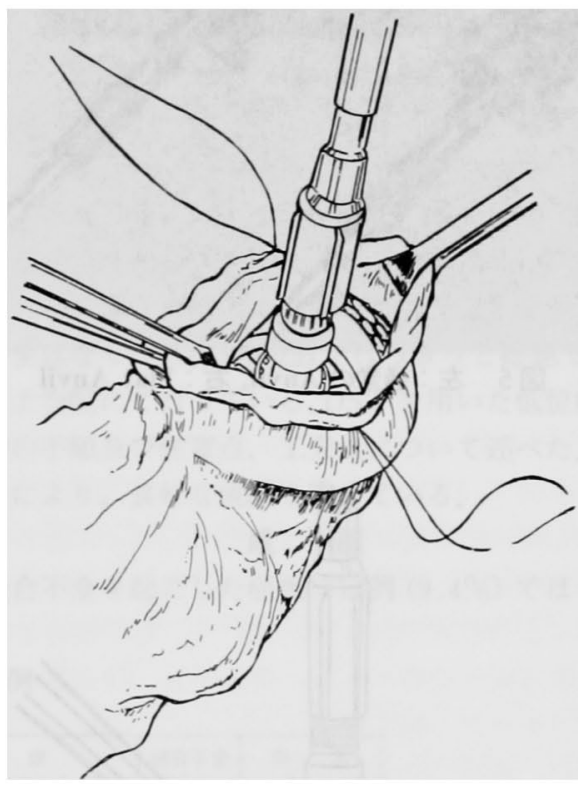

图 4

Roticulator ううを用いているが，組織の厚さに応じて， 針の高さが異なる2種類（先端の色が青色と緑色）を 使い分けている。さらに狭骨盤で超低位前方切除術で， 直腸が細い場合には、幅の狭いタイフを用いている。

(5) 続いてロ側の腸管へのAnvil 挿入操作に移る が, 断端の腸管より口側へ腸鉗子をかけタバコ桻合器 をはずし，アリス鉗子にて 2 点支持して生食水約 10〜20 ml を注入し, 腹腔外にて Anvil を挿入する.以 
前はキシロカインゼリーを Anvil に染布していたが, 吻合までに時間がかかる際乾燥してしまいPCEEA 本体を抜去する時に困難となる(図4).Anvil には通 常タイプのものと, 上部消化管用の Flat Anvil がある (図 5 ).

Anvil 挿入の際, 通常タイプの場合, 断端直上から腸 管壁をすべらせる様に入れる為, 腸管壁が脆弱だった り狭い場合裂ける事があり, 径31mm 大が入らず径28 $\mathrm{mm}$ 大を使用せざるを得ない場合がある。そこで当院 では半年前から上部消化管用の Flat Anvil を用い, Anvil の側壁より挿入する事によって容易に装着でき る(図 6a, b).

(6) 吻合の準備が整った後,再度緊張がないかどうか

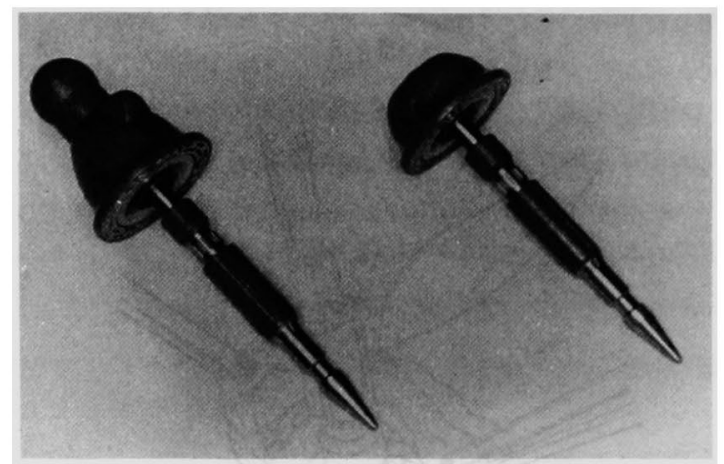

図 5 左：通常の Anvil, 右：Flat Anvil

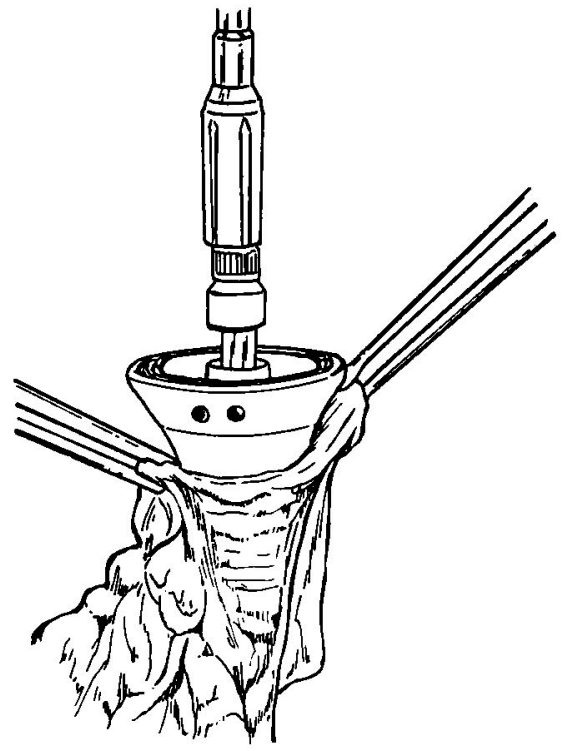

図 6a 通常の Anvil 㨉入操作

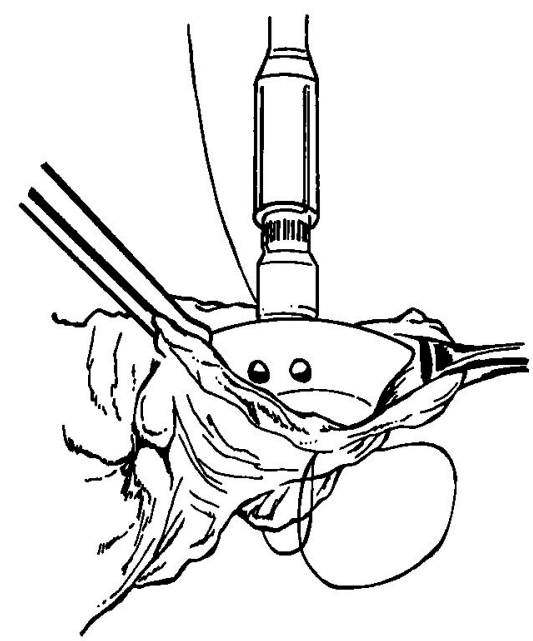

图 6b Flat Anvil の抙入操作

を確認し，口側の腸管が恥骨結合上緑まて届かない場 合, 脾罗曲部を剥離する。

(7)次に吻合操作に移るが，まず会陰部に移り PCEEA 本体を肛門より挿入するが, 寿核, 致肛, 表渡 などのなんらかの肛門疾患を合併している場合, 簡単 には入らない．そこで当院では，開腹する前に肛門筧 にて充分拡張させている.それでも挿入できない場合， 肛門後方の内括約筋を切開している. 無理な操作て PCEEA 本体を挿入すると，直腸断端を損傷したり括 約筋を無理に伸展する為, 術後の Incontinence の一因 ともなる。

(8) PCEEA 本体が断端近傍に達した時点で腹腔内 から器械を誘導し，断端中央にセンターロッドが来る 様に固定する.トロッカーを抜去し, Anvil をセンター ロッドに装着し，PCEEA を右方向に回転させて吻合 に入るが,この際，口側の腸管の両端を軽く引っ張り Anvil 装着面が充分伸展する様にして, 腸管を寄せ合 わせる様にする．PCEEA 本体の緑色のマーカーが見 えた時点でファイヤーする.

(9) PCEEA 本体を抜去する際, 通常の Anvil では八 ンドルを 3 回転ないし 3 回転半左に回していたが, Flat Anvil の場合, 1 回転半程度で容易に抜去できる。 又, 拔去の方法として, 左手第II指を肛門内に挿入し， 器械に添える様にして，8の字を描く様にして引き报 $<($ 図 7$)$.

(11)吻合が終了した時点で，口側の腸管に鉗子をか け，術中ファイバーにて吻合部を確認するとともに， 生食水 $1,000 \sim 2,000 \mathrm{ml}$ を腹腔内に注入し, 肛門から 


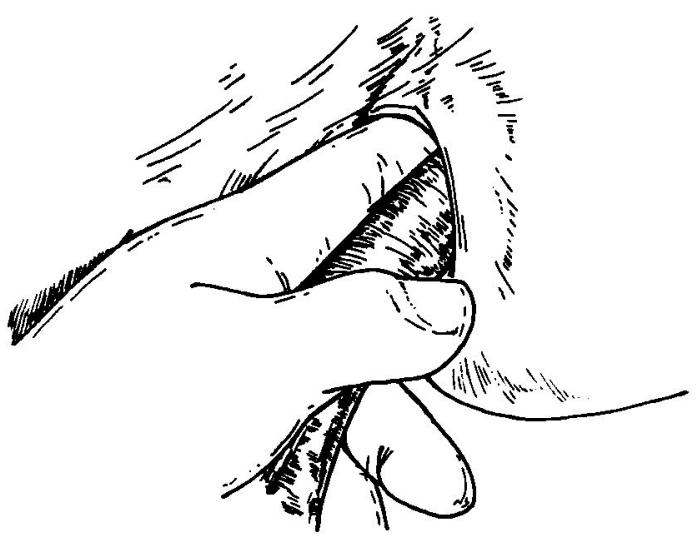

図 7 PCEEA の抜去操作

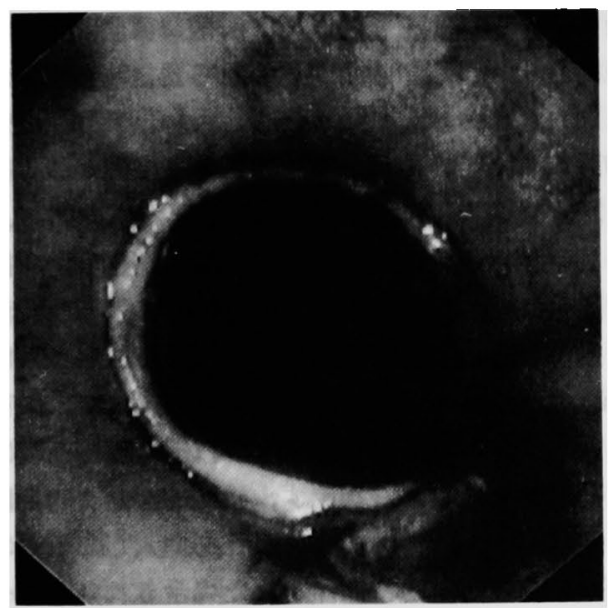

図8術中内視鏡による吻合部钼察

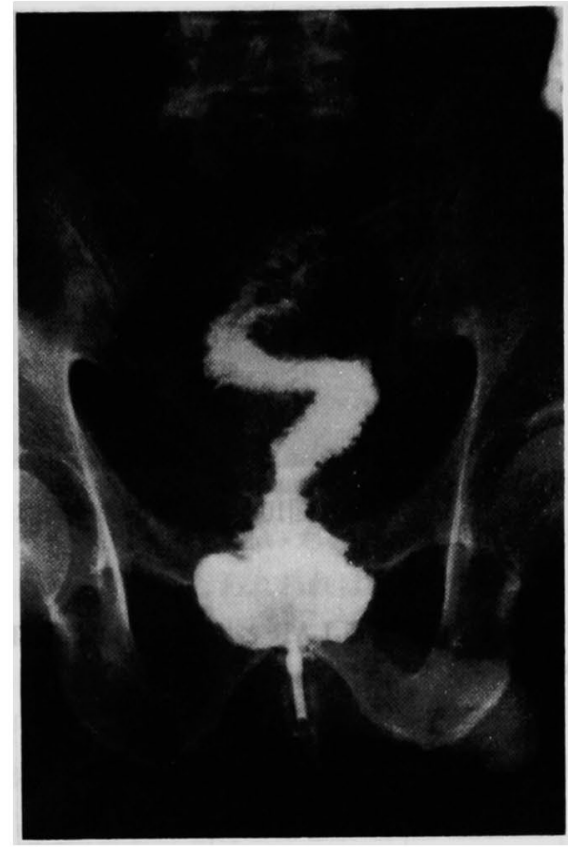

図 9 術後 7 日目の吻合部造影

air を入れ, leak test を施行する. 図 8 は吻合部の写 真を示す、スティプルによって吻合がきれいに完成さ れている. 図 9 は術後 7 日目の吻合部造影を示す。縫 合不全はなく,吻合部の位置をはっきりと確認できる。

以上当院にて行っている，DST を用いた低位前方切 除術の手順及び注意点，工夫点について述べた。この 方法により，良好な成績を納めている．

成 績

縫合不全を起こした症例は13例 (9.4\%) でほとんど

表 I 術後狭窄症例

\begin{tabular}{|c|c|c|c|c|c|c|c|}
\hline 症例 & 行 式 & 性 & 年此 & Stage & 合 併 店 & 䛧合不全 & 爸 \\
\hline 1 & LAR & $M$ & 65 & $m \rho n_{0}{ }^{p_{0}} H_{0} M(-)$ & 括環器（不整脈） & $(-)$ & 用指的ブジー \\
\hline 2 & LAR & $M$ & 70 & $m p n_{0}{ }^{D_{0}} H_{0} M(-)$ & 肝機能㜔害 & $(-)$ & 用指的ブジー \\
\hline 3 & LAR & $M$ & 69 & ss $n_{0} p_{0} H_{9} H(-)$ & 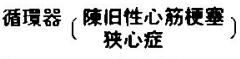 & $(+)$ & 用指的フジー \\
\hline 4 & LAR & $M$ & 59 & $\underset{m p n_{0} p_{0} H_{0} M(-)}{\|\|}$ & 活㻴器 (高血圧) & $(-)$ & 用指的ブジー \\
\hline 5 & LAR & $M$ & 59 & $m_{0} n_{0} D_{0} H_{0} M(-)$ & $(-)$ & $(-)$ & 人工肘門造設 \\
\hline 6 & LAR & $M$ & 49 & $\stackrel{\text { I }}{m p n_{0} D_{0} H_{0} M(-)}$ & $(-)$ & $(-)$ & 用指的ブジー \\
\hline 7 & LAR & $F$ & 40 & $\frac{1}{m p n_{0} p_{0} H_{0} M(-)}$ & $(-)$ & $(-)$ & 用指 \\
\hline
\end{tabular}



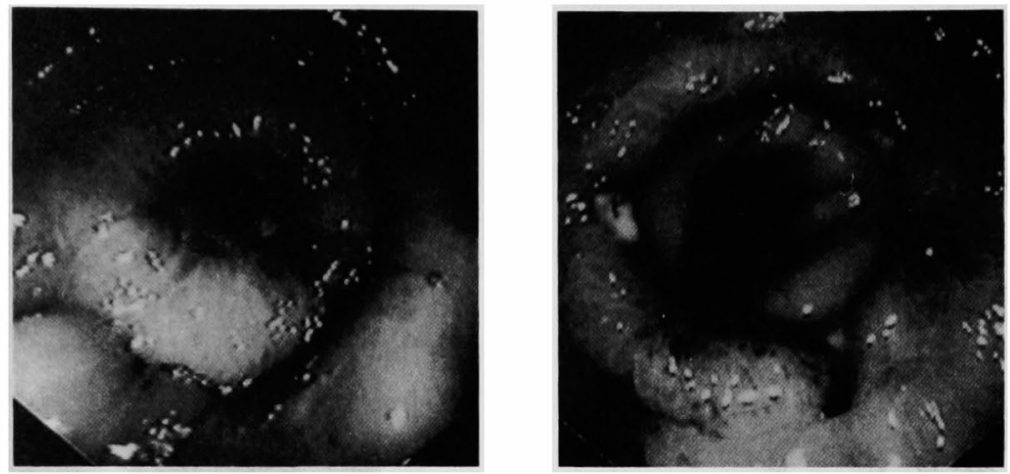

図10 左 : 術後の吻合部狭窄像，右：用指的ブジー施行後の内視鏡像

表 2 器械吻合による LAR と用手吻合による HAR の比較

\begin{tabular}{|c|c|c|}
\hline 濑 式 & 低位前方切除蔽 & 离位前方切檍術 \\
\hline 症 & 138 & 35 \\
\hline 粹 & $63.1 \pm 10.7$ & $63.1 \pm 10.4$ \\
\hline 性比（U:F) & $85: 53$ & $20: 15$ \\
\hline 狭䇤 例 & $7(5.1 \%)$ & $1(2.8 \%)$ \\
\hline 醚合不全例 & $13 \quad(9.4 \%)$ & 1 (2.8\%) \\
\hline
\end{tabular}

LAR: 低位前方切除㭪 HAR: 高位前方切除術

1988年 1 月 1992年12月

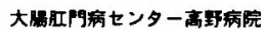

初期の症例で, IVH 及び横行結腸の人工肛門造設など で治瘾した。吻合部狭窄例は 7 例 $(5.1 \%)$ に認められ たが，1例は人工肛門造設を行い，他の 6 例は用指的 ブジーにより改善がみられた(表 1 )。用手吻合を行っ た高位前方術と比較すると，縫合不全，吻合部狭窄と も高率であった（表 2 ).

実際に，術後の吻合部狭窄例を呈示する，症例は69 歳男性で，Raの[Borrmann] II 型の癌に対して低位 前方切除術を施行した症例である，左側が狭窄時，右 側が用指的フジー施行後の内視鏡像である．狭窄は， ブジー後明らかに改善が認められている(図10)。この 様に，吻合部が第II 指の届く範囲内にあれば，用指的 ブジーにより容易に狭窄が改善される.

\section{考 察}

近年直腸癌に対して, 多くの施設において器械吻合 が行われる様になってきた。1979年に Ravitch"らによ り直腸癌に対する器械吻合が導入され，1980年に
Knight \& Griffen ${ }^{2}$ が，現在の DST による低位前方切 除術 (以下 LAR) を報告した。一般に直腸癌に対する 器械吻合は, 瞬時に吻合が行われる為, 吻合部位が低 位になればなるほど失敗は許されない．特に超低位前 方切除術の場合, 器械の操作を誤ると milesの手術に なり，永久的人工肛門が余儀なくされる. 従って，わ れわれ直腸癌の治療に従事する者は, 器械吻合の操作 に習熟しなければならない.DSTによる器械吻合がう まくいかない場合としては，次の様な事が举げられる.

(i) 肛側の切離端に Roticulator をかけて, 針を打 ち込む前にメスで切離してしまう.（ii）直腸断端の適 切な部位にトロッカーが出ず, 生理的な端々昒合にな らない.（iii）口側腸管の, Anvil を挿入した断端の脂 肪組織が厚い為, 吻合操作をした場合きれいなドーナ ツ状のリングがとれない. (iv) PCEEA 本体を肛門か ら挿入する際，直腸断端を強く压迫し損傷する（ $(\mathrm{v})$ 吻合終了時, PCEEA 本体を抜去する際に吻合部を損 傷する.

当院では，以上述へた様な Pit fall に陥らない様に 適応を慎重にし，いくつかの工夫を加えている. まず DST を用いた LAR の適応として, 腫場の位置が肛門 縁から5〜 $12 \mathrm{~cm}$ の範囲にあり ${ }^{3)}$, 腫場の周辺臟器への 高度な浸潤がみられない4, リンパ節転移が高度で あっても身体的状況を考虑した上で，姑息的手術とし て適応ありと判断した場合はなどが考えられる.腫瘍 の肛門緑からの位置に関しては各施設によって差があ ると思われるが（イ）吻合部の高さによる術後の排便 機能に差が認められない.（口）肛門縁からの距離のみ でなく，性別や骨盤の形によって，可能かどうかが決 まる.この 2 点により, 当院では可能な限りDSTを用 いた LAR を施行する様にしている. 
当莞で行っているいくつかの工夫点をまとめると， 第 1 点は, まず口僓湟管へAnvil を㧴入する際,でき るだけ口径の大きな物を用いることが望ましいが，通 常の Anvil の場合上からねじ込む様に㨉入するので， 腸管壁を椇傷する可能性がある。そこでわれわれは, 食道雷の吻合に用いる Flat Anvil を側壁よりボタン をかける様に挿入している，後に PCEEA を抜去する 際に楽に抜去てきる。第 2 点は, PCEEA 本体を肛門よ り㨉入する際，肚門疾患を合併していてなかなか入ら ない場合, 電気メスにて肛門後方の内括約筋を一部切 開することにより容易に扱入可能となる. 第 3 点は, 術中ファイバーにて必ず吻合部を確認し，腹㬵内に生 食水を注入してファイバーより air を送ることによっ て, leak test を施行する様にしている. 第 4 点は, 術 後の吻合部狭窄に備えて，吻合部位をできるだけ第 II

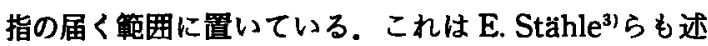
ぺている様に，吻合部の高さによる術後の排便機能に 差がみられないという事に基ゔいている．当院におい ても 1 年後には, LAR 群と Super LAR 群との間に, 術後の排便機能に差はみられなかった。

街後の大きな合併症として縫合不全と吻合部狭窄が 挙げられる，まず縫合不全については，各施設さまざ まであるが，一般的にはその頻度は $10 \%$ 前後と報告さ れている5．当院においても9.4\%であった．縫合不全 を起こした場合の処置としては, IVH あるいは横行結 腸の人工肛門造設を行い, 重篤な場合は開腹洗浄を 行った後，人工肛門を造設している，次に吻合部狭窄

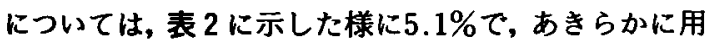
手吻合による高位前方切除術に比べその頻度は高かっ た. Knight \& Griffen ${ }^{2} ら$ は $3 \%$, Gordon, Dalrymple ${ }^{6)}$

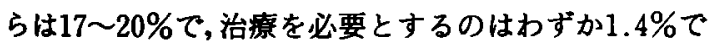
あったと報告している．われわれは吻合部狭窄の定義 として，細径ファイパー（PCF）が通過しないものと している. 又，原因として表 3 の様な因子を考えてい

\section{表 3 吻合部狭寉の原因}
1、器找吻合後に爾强の系をかけ すぎる
2. 野管がかしれたり，吻合部に 霜張か挂かる
3. 吻合部の血目形成
4. 器诚のS Z ZEが不逼切
5. ANV I L拔去時の吻合部提但

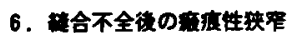

るが，1に関しては，㭪強の系はなるべくかけない様 にしている，2に関しては，口側の結腸が恥骨上緑ま で届く様に授動している４４器械のサイズについて は，なるべく大きなサイズを使用する様にしているが， 狭窄が EEAのサイスとは無関保に発生しているとい う報告もある゙。いずれにしても，EEA は腸管の内径 に合った無理のない大きさを使用すべきであるといえ ろ. 5 については, Anvil 抜去時左II指を添えて，でき るだけゆっくりと行う樣にしている。一般的に器械吻 合は，一層の全層䋖合て疫痕治疮を柤ったものであり， 粘膜下層同士を合わせる用手吻合に比べ伸展性がな く，狭窄を来しやすいといえる．この事はある程度避 けられない事であり，われわれは吻合部狭窄に備えて， 用指フジーを行いやすい様に，できるだけ指の届く籍 囲に吻合部を置く样にしている。

以上, DSTによる LAR は, 少数ながら縫合不全, 吻合部狭窄などの合併症が発生し得るが，より低位て の吻合が短時間で可能であり，術中の污染がなく，腫 瘏の Implantationなども避けられるという利点があ り，さまざまな工夫を加えることによって，良好な成 績が納められると思われた。

結語

（i）当院におけるDSTによるLAR の工夫につい て述べた。

（ii）DSTによるLAR は，縫合不全，吻合部狭窄な どの合併症が，用手吻合による高位前方切除術に比べ 高頻度で，これに対する対策が重要と思われた。

\section{文献}

1) Ravitch MM, Steichen FM : A stapling instrument for end-to end inverting anastomosis in the gastrointestinal tract. Ann Surg $189: 791-$ 797, 1979

2) Griffen $F D$, Knight $C D$, John $M$ : The double stapling technique for low anterior resection. Ann Surg 211: 745-751, 1990

3) Stähle E, Pählman L, Enblad P: Double stapling technique in the management of rectal tumors. Acta Chir Scaud 152 : 743-747, 1986

4）高田秀穂，山本政勝：直腸癌の手術：低位前方切 除術. 消外 8:124-135, 1985

5) Varma JS, Chan ACW, Li MKW, et al: Low anterior resection of the rectum using a double stapling technique. Br JSurg $77: 888-890,1990$

6) Gordon PH, Dalrymple S: The use of staples 
for reconstruction after colonic and rectal surgery. In Ravitch MM, Steichen FM, eds Principles and Practice of Surgical Stapling, Year Book Medical Publishers. Chicago, 1987, p402-
431

7) 田中昭吉, 水田英司, 内山哲史他：器械吻合を用い た直腸癌低位前方切除術の術後合併症とその対 策. 山口医 $39: 443-447,1990$

\title{
THE DEVICE LOW ANTERIOR RESECTION USING DOUBLE STAPLING TECHNIQUE FOR RECTAL CANCER
}

\author{
Naoyuki FUJIMOTO, Masahiro TAKANO, Koichi TAKAGI, Ryuichi KIKUCHI, \\ Toshiya TANAKA, Masazumi KUROKI and Shinichiro MAGATA \\ Coloproctology Center Takano Hospital \\ Tateshi FUJIYOSHI \\ Fujiyoshi Clinic
}

We have added the following devices for low anterior resection using double stapling technique. (1) When inserting anvil for the oral intestine, the flat anvil is inserted from the lateral wall like one fasten buttons. (2) When inserting PCEEA from the anus, in the case complicating by some anal disease, a part of the posterior internal sphincter is cut using an electric mes. (3) We always confirm the part of anastomosis by colonoscope and do the leak test. (4) The anastomosis is kept within the sphere of reached the second finger providing for postoperative anastomotic stenosis.

The postoperative complications included leakage $9.4 \%$ and anastomotic stenosis $5.1 \%$. These results were satisfactory. The low anterior resection using double stapling technique can produce a few postoperative complications.

The method, however, can be expected to provide excellent outcomes, because it is possible to anastomose at a more lower site in a short operation time and no intraoperative contamination occurs by several devices. 